Reprod. Nutr. Dévelop., 1983, 23 (2 A), 303-308.

\title{
Effect of the relative locations of embryo and corpus luteum on embryo survival in cattle
}

\author{
M. R. DEL CAMPO, R. F. ROWE, Daung CHAICHAKEUN, O. J. GINTHER \\ Department of Veterinary Science, University of Wisconsin-Madison, \\ Madison, Wisconsin 53706, U.S.A.
}

\section{Summary.}

The cbjectives were to determine if early in gestation $(<$ day 30$)$ an embryo in the ipsilateral horn increases the survival rate of an embryo in the contralateral horn and if later in gestation ( $>$ day 30 ) the presence of two embryos adversely affects the survival of both embryos in cattle. The experiment involved surgical embryo transfer. Sixty Holstein heifers were assigned to 4 groups : group 1) sham bilateral transfers, group 2) one embryo inserted ipsilateral to $C L$, group 3) one embryo inserted contralateral to $C L$, and group 4) one embryo inserted into each horn. Diagnosis of pregnancy and ovarian activity were recorded from day 7 or 8 (surgery) to day 110. Results indicated that the rate of embryo survival early in pregnancy ( $<$ day 30 ) in heifers with the embryo inserted contralateral to the $\mathrm{CL}(33 \%$, group 3$)$ was increased $(\mathrm{P}=0.05)$ when an embryo was also inserted into the ipsilateral horn (67\%, group 4). The hypothesis that the ipsilateral embryo would have a protective effect on the contralateral embryo was, therefore, supported. This may have been due to the prevention of luteolysis by the ipsilateral embryo. However, when an embryo was present in each horn considerable loss occurred > day 30 resulting in a low survival rate by day $110(27 \%)$. The hypothesis that the presence of two embryos would decrease the survival probability of both embryos later in gestation was, therefore, supported.

\section{Introduction.}

It is common practice in embryo transfer in cattle to insert the embryo into the horn ipsilateral to the ovary bearing the corpus luteum (CL). Pregnancy rates of $31 \%$ to $75 \%$ have been obtained (Hahn and Hahn, 1976; Rowe et al., 1976), but the rate of loss of embryos early in gestation apparently has not been critically investigated. Using single embryo transfer, Newcomb and Rowson (1980) reported a higher survival rate of ipsilateral embryos (46\%) than contralateral embryos (0\%). In another study (Tervit et al., 1977) a lower pregnancy rate was obtained with contralateral placement of an embryo (39\%), than with ipsilateral placement (54\%). Christie et al. (1979) have indicated that great numbers of developing embryos died between days 24-42 when transfers were done into the contralateral horn. 
Using bilateral embryo transfer (one embryo into each horn), Sreenan and coworkers (1975) reported reduced embryo survival on the contralateral side, but in a later report (Sreenan and Beehan, $1976 \mathrm{a}, \mathrm{b}$ ) concluded that the position of the embryo relative to the $\mathrm{CL}$ did not seem to affect embryo survival. Other workers obtained survival rates of $51 \%$ and $36 \%$ for ipsilateral and contralateral placement, respectively (Heyman and Renard, 1978), but the difference was not significant.

A unilateral relationship between embryo and $C L$ has been demonstrated conclusively by surgical separation of uterine horns; $C L$ regressed when two embryos were inserted contralaterally, and $\mathrm{CL}$ were maintained when embryos were inserted ipsilaterally (Del Campo et al., 1977). However, contralateral embryos were capable of maintaining the $C L$ to day 24 if the uterine horns were intact, but the weight of the maintained $C L$ was reduced. In addition to an apparent increased incidence of early $(<$ day 30$)$ loss of embryos in the contralateral position, considerable subsequent embryonic and fetal death occurs in association with twin ovulations (Kidder et al., 1952 ; Gordon et al., 1962 ; Scanlon, 1972) or transfer of twin embryos (Sreenan and Beehan, 1976 a, b ; Newcomb et al., 1978 ; Anderson et al., 1979). In a recent study loss of the conceptuses occurred in $20 \%$ of recipients that were diagnosed pregnant at 45-60 days (Anderson et al., 1978).

This experiment was conducted to test the following hypotheses in cattle : 1) early in gestation ( < day 30) an embryo in the ipsilateral horn increases the survival rate of an embryo in the contralateral horn, and 2) later in gestation ( $>$ day 30 ) the presence of two embryos adversely affects the chances for survival of both embryos.

\section{Materials and methods.}

A total of 86 Holstein heifers, approximately 15-20 months of age, was used in an experiment involving embryo transfer (26 donors, 15 sham-operated recipients and 45 recipients of embryos). Heifers were observed twice daily for estrus. Day of standing estrus was designated day 0 of the estrous cycle. Recipient heifers were synchronized to within \pm 24 hours of donor heifers.

Embryos were collected from donors on day 7 or 8 post estrous by a nonsurgical technique (Rowe et al., 1980) and were examined microscopically for stage of cleavage and abnormalities. The flushing medium was tissue culture medium (TCM) 199 (a) containing $100 \mathrm{IU}$ potassium penicillin $\mathrm{G}\left({ }^{\mathrm{b}}\right), 100 \mathrm{mcg}$ streptomycin sulfate (c), and $1 \mathrm{mg}$ bovine serum albumin (d) per $\mathrm{ml}$ (Rowe et al., 1976). Embryos classified as normal and in the morula or blastocyst stage were placed in fresh tissue culture medium and kept in an incubator at $37{ }^{\circ} \mathrm{C}$ until transfers were done.

\footnotetext{
(a) Flow Laboratories, Rockville, Maryland.

(b) GIBCO, Grand Island, N.Y.

(c) Pfizer, Inc., New York, N.Y.

(d) Sigma Chemical Co., St. Louis, Missouri.
} 
Recipients were randomly assigned to 4 groups : group 1) sham bilateral transfers (control), group 2) one embryo ipsilateral to the CL (ipsilateral), group 3) one embryo contralateral to the CL (contralateral), and group 4) one embryo ipsilateral and one embryo contralateral (bilateral).

Transfer of embryos (selected at random) was done into standing recipients by a flank approach under local anesthesia (Rowe et al., 1979). Surgical manipulations and insertion of the embryo for the left horn was done through the left flank and for the right horn through the right flank. Both flanks were opened at the same time by two different operators. Penicillin and streptomycin were given prior to closure of the flank incisions. Transfers (embryos or sham) into the uterine horns were done by the same operator for all heifers. The uterine horns were exposed and punctured 30 to $40 \mathrm{~mm}$ from the uterotubal junction with the blunt end of a stylet, and 0,1 , or 2 embryos were inserted into the lumen of the uterine horns. Only tissue culture media (approximately $0.2 \mathrm{ml}$ ) was inserted into the horns in the sham-operated group and into the horn that did not receive an embryo in groups 2 and 3 .

Recipients were examined by rectal palpation and ovarian activity was recorded every 4 days from day of surgery to day 60 , and pregnancy was recorded approximately every 10 days from day 30-110. At day 30 diagnosis of pregnancy was done under epidural anesthesia to facilitate examination. A positive diagnosis of pregnancy was recorded only when an amniotic vesicle was palpated or when fluid in the horns, slip of the allantochorion, difference in size of horns, and a maintained CL were found together. Recipients that showed estrus before day 110 were palpated until a new ovulation occurred. Differences in pregnancy rate among groups 2-4 at day 30 and pregnancy loss at day 110 were analyzed by Chi-square. For the sham-operated controls (group 1) and the recipients that were classified as not pregnant at day 30 in groups 2-4, estrous cycle length and diameter of $C L$ were individually analyzed by one way analysis of variance (ANOVA). If ANOVA indicated significant effects, the means were compared by Duncan's new multiple-range test.

\section{Results.}

Twenty-six of the 45 recipients that received embryos were classified as pregnant at day $30: 11$ of 15 in the ipsilateral group, 5 of 15 in the contralateral group, and 10 of 15 in the bilateral group (fig. 1). In all pregnant heifers in the bilateral-group, embryo survival involved both sides.

At day 30 the pregnancy ratio was different $(P=0.05)$ among the three groups, due primarily to a reduced pregnancy rate in the contralateral group. The ratio for loss of pregnancy between days 30-110 was different $(P<0.05)$ among ipsilateral, contralateral, and bilateral groups, due primarily to a greater loss of embryos in the contralateral and bilateral groups.

Transuterine migration of embryos was not found in any heifer. Mean interestrous intervals for the control heifers and the nonpregnant heifers were : control group, $21.3 \pm 0.4$ (SEM) ; ipsilateral group, $21.0 \pm 0,8$; contralateral 


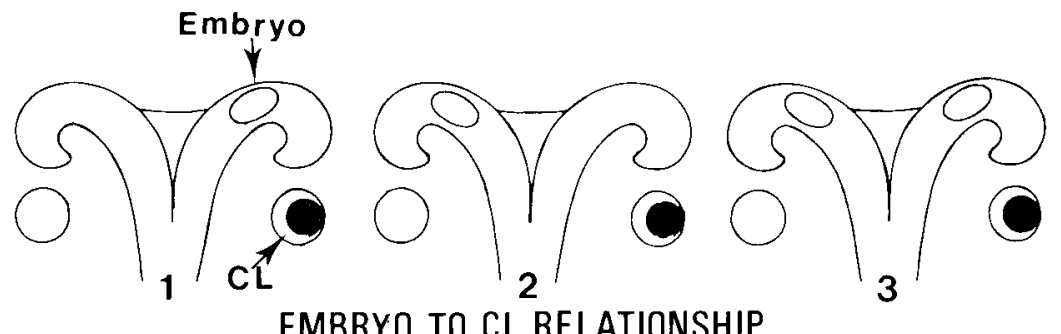

\begin{tabular}{|c|c|c|c|c|c|c|}
\hline \multirow[b]{2}{*}{ Day } & \multicolumn{2}{|c|}{ IPSILATERAL } & \multicolumn{2}{|c|}{ CONTRALATERAL } & \multicolumn{2}{|c|}{ BILATERAL } \\
\hline & Pregnant & $\begin{aligned} & \text { Lost } \\
> & \text { day } 30\end{aligned}$ & Pregnant & $\begin{aligned} & \text { Lost } \\
> & \text { day } 30\end{aligned}$ & Pregnant & $\begin{aligned} & \text { Lost } \\
> & \text { day } 30\end{aligned}$ \\
\hline 30 & $11 / 15^{*}$ & - & $5 / 15^{*}$ & - & $10 / 15^{*}$ & - \\
\hline 40 & $11 / 15$ & $0 / 11$ & $3 / 15$ & $2 / 5$ & $8 / 15$ & $2 / 10$ \\
\hline 50 & $10 / 15$ & $1 / 11$ & $2 / 15$ & $3 / 5$ & $7 / 15$ & $3 / 10$ \\
\hline 60 & $10 / 15$ & $1 / 11$ & $2 / 15$ & $3 / 5$ & $7 / 15$ & $3 / 10$ \\
\hline 70 & $10 / 15$ & $1 / 11$ & $2 / 15$ & $3 / 5$ & $7 / 15$ & $3 / 10$ \\
\hline 80 & $10 / 15$ & $1 / 11$ & $2 / 15$ & $3 / 5$ & $6 / 15$ & $4 / 10$ \\
\hline 90 & $10 / 15$ & $1 / 11$ & $2 / 15$ & $3 / 5$ & $5 / 15$ & $5 / 10$ \\
\hline 100 & $10 / 15$ & $1 / 11$ & $2 / 15$ & $3 / 5$ & $5 / 15$ & $5 / 10$ \\
\hline 110 & $10 / 15$ & $1 / 11^{* *}$ & $2 / 15$ & $3 / 5^{* *}$ & $4 / 15$ & $6 / 10^{* *}$ \\
\hline
\end{tabular}

FIG. 1. - Effect of location of embryos and the corpus luteum on pregnancy rate.

* : Ratios are different $(P=0.05)$.

**: Ratios are different $(P<0.05)$.

group, $22.7 \pm 1.2$; and bilateral group, $26.2 \pm 2.7(\mathrm{P}<0.05)$. There were no significant differences for diameter of $C L$ for the nonpregnant recipients.

\section{Discussion.}

The results of this experiment indicated that the rate of embryo survival early in gestation ( $<$ day 30 ) in heifers with an embryo inserted contralateral to the CL (33\%, group 3) was increased when an embryo was also inserted into the ipsilateral horn $(67 \%$, group 4$)$. The hypothesis that an ipsilateral embryo would have a protective effect on the contralateral embryo early in gestation was therefore supported. Most likely this protective effect involved prevention of luteolysis by the ipsilateral embryo (Del Campo et al., 1977). However, in the 
bilaterally pregnant recipients gradual loss of embryos occurred after day 30 , and in all cases loss of embryos occurred on both sides. The hypothesis that later in gestation the presence of two embryos would adversely affect the survival probability of both embryos was therefore supported. In summary, the early positive effect of the ipsilateral embryo on the survival of the contralateral embryo became a negative effect later in gestation. Some loss of embryos occurred after day 30 in the ipsilateral and contralateral groups, but all of these losses occurred by day 50 . The causes of the high embryo mortality after day 30 in the bilaterally pregnant heifers are unknown. Similar results have been reported by Anderson et al. (1978) who found a high pregnancy rate on days 4560 in heifers that received one embryo in each uterine horn $(75 \%)$ and a gradual loss of pregnancy later in gestation.

Reçu en août 1982.

Accepté en novembre 1982.

Acknowledgments. - Supported by the College of Agricultural and Life Science, University of Wisconsin and by a grant from USDA Science and Education Administration. Parts of these data were presented at the 71st Annual Meeting of the American Society of Animal Science.

The authors wish to thank the UpJohn Company, Kalamazoo, Michigan and American Breeders Service, DeForest, Wisconsin for the generous donations of prostaglandin $F_{2 \alpha}$ and semen, respectively, and Mr. L. Freedman for technical assistance.

Résumé. Effets de l'emplacement relatif de l'embryon et du corps jaune sur la survie de l'embryon chez les bovins.

Ce travail, réalisé chez les bovins, a un double objet: 1) déterminer si avant le $30^{\mathrm{e}}$ jour de gestation la présence d'un embryon dans la corne ipsilatérale au corps jaune favorise la survie d'un embryon placé dans la corne contralatérale ; 2) rechercher si, après le $30^{\mathrm{e}}$ jour de gestation, la présence simultanée de deux embryons dans l'utérus a un effet défavorable sur leur survie.

Dans cette expérience on a utilisé le transfert d'embryons par voie chirurgicale.

Soixante génisses de race Holstein ont été réparties en 4 groupes : 1er groupe : transfert bilatéral simulé ; $2^{\mathrm{e}}$ groupe : transfert d'un seul embryon dans la corne ipsilatérale au corps jaune ; $3^{\text {e }}$ groupe : transfert d'un embryon dans la corne contralatérale au corps jaune ; $4^{\mathrm{e}}$ groupe : transfert d'un embryon dans chaque corne.

L'activité ovarienne a été contrôlée jusqu'au $60^{e}$ jour après l'intervention. L'état de l'utérus a été examiné du $30^{\mathrm{e}}$ au $110^{\mathrm{e}}$ jour. Les résultats indiquent qu'avant le $30^{\mathrm{e}}$ jour le taux de survie de l'embryon placé dans la corne contralatérale augmente lorsqu'un embryon est présent dans la corne ipsilatérale au corps jaune. Ce fait pourrait être dû à la prévention de la lutéolyse par l'embryon ipsilatéral. Par contre, la présence simultanée après le $30^{\mathrm{e}}$ jour d'un embryon dans chaque corne abaisse très fortement le taux de survie au $110^{\mathrm{e}}$ jour.

\section{References}

ANDERSON G. B., CUPPS P. T., DROST M., HORTON M. B., WRIGHT Jr. R. W., 1978. Induction of twinning in beef heifers by bilateral embryo transfer. J. anim. Sci., 46, 449-452. ANDERSON G. B., CUPPS P. T., DROST M., 1979. Induction of twins in cattle with bilateral and unilateral embryo transfer. J. anim. Sci., 49, 1037-1042. 
CHRISTIE W. B., NEWCOMB R., ROWSON L. E. A., 1979. Embryo survival in heifers after transfer of an egg to the uterine horn contralateral to the corpus luteum and the effect of treatments with progesterone on hCG on pregnancy rates. J. Reprod. Fert., 56, 701-706.

DEL CAMPO M. R., ROWE R. F., FRENCH L. R., GINTHER O. J., 1977. Unilateral relationship of embryos and the corpus luteum in cattle. Biol. Reprod., 16, 580-585.

GORDON J., WILLIAMS G., EDWARDS J., 1962. The use of serum gonadotropin (PMS) in the induction of twin-pregnancy in the cow. J. agric. Sci., 59, 143-198.

HAHN J., HAHN R., 1976. Experience with nonsurgical transfer techniques. Egg transfer in cattle. VIIIth int. Congr. Anim. Reprod. art. Insem., Krakow, p. 199-204.

HEYMAN Y., RENARD J. P., 1978. Production de jumeaux par transplantation d'embryons chez les bovins de race à viande. Ann. Méd. vét., 122, 157-163.

KIDDER H. E., BARRET G. R., CASIDA L. E., 1952. A study of ovulations in six families of Holstein-Friesians. J. Dairy Sci, 35, 436.

NEWCOMB R., CHRISTIE W. B., ROWSON L. E. A., 1978. Comparison of the fetal survival rate in heifers after the transfer of an embryo surgically to one uterine horn and nonsurgically to the other. J. Reprod. Fert., 52, 395-397.

NEWCOMB R., ROWSON L. E. A., 1980. Investigation of physiological factors affecting nonsurgical transfer. Theriogenology, 13, 41-49.

ROWE R. F., DEL CAMPO M. R., EILTS C. L., FRENCH L. R., WINCH R. P., GINTHER O. J., 1976. A single cannula technique for nonsurgical collection of ova from cattle. Theriogenology, 6, 471-483.

ROWE R. F., DEL CAMPO M. R., CRITSER J. K., GINTHER O. J., 1979. Embryo transfer in cattle : Nonsurgical transfer. Am. J. vet. Res., 41, 1024-1028.

ROWE R. F., DEL CAMPO M. R., CRITSER J. K., GINTHER O. J., 1980. Embryo transfer in cattle : Nonsurgical collection techniques. Am. J. vet. Res., 41, 106-108.

SCANLON P. F., 1972. Frequency of transuterine migration of embryos in ewes and cows. $J$. anim. Sci., 34, 791-794.

SREENAN J. M., BEEHAN D., 1976 a. Embryonic survival and development at various stages of gestation after bilateral egg transfer in the cow. J. Reprod. Fert., 47, 127-128.

SREENAN J. M., BEEHAN D., $1976 \mathrm{~b}$. Effect of site of transfer on pregnancy and twinning rates following bilateral egg transfer in the cow. J. Reprod. Fert., 48, 223-224.

SREENAN J. M., BEEHAN D., MULVEHILL P., 1975. Egg transfer in the cow : Factors affecting pregnancy and twinning rates following bilateral transfers. $J$. Reprod. Fert., 44, 77-85.

TERVIT H. R., HAVIK P. G., SMITH J. F., 1977. Egg transfer in cattle : Pregnancy rate following transfer to the uterine horn ipsilateral or contralateral to the functional corpus luteum. Theriogenology, 7, 3-8. 